\title{
ENTREPRENEURIAL INTENTION DITINJAU DARI \\ ENTREPRENEURIAL MOTIVATION DAN EDUCATION MAHASISWA MANAJEMEN UNIVERSITAS CIPUTRA
}

\author{
Feilany Tali \\ Program Studi International Business Management \\ Fakultas Manajemen Bisnis Universitas Ciputra \\ UC Town, Citraland, Surabaya \\ Liliana Dewi \\ Program Studi International Business Management \\ Fakultas Manajemen Bisnis Universitas Ciputra \\ UC Town, Citraland, Surabaya
}

\begin{abstract}
The purpose of this research is to know the influence of Entrepreneurial Motivation and Entrepreneurship Education toward Entrepreneurial Intention on Faculty of Business Management, Ciputra University. The sample were used 93 students. This research used a quantitative research, random sampling and data was collect by questionnaire. The analysis technique used correlation pearson, cronbach alpha, multiple linear regression, $t$ test, $F$ test, and classical assumptions test. The result of multiple linear regression analysis is $\hat{\mathrm{Y}}=0,750+$ $0,585 \mathrm{X}_{1}+0,240 \mathrm{X}_{2}$, that means entrepreneurial intention influenced by entrepreneurial motivation and entrepreneurship education. Based on the results of study, it was found: 1) entrepreneurial motivation have positive and significant impact on entrepreneurial intention; based on multiple linear regression analysis ( $t$ test), is known $t_{\text {count }}>t_{\text {table }}(5.331>1.818)$ and the significance value $<0.05(0,000) .2)$ entrepreneurship education have positive and significant impact on entrepreneurial intention; based on multiple linear regression analysis ( $t$ test), is known $t_{\text {count }}>t_{\text {table }}(3,077>1,818)$ and the significance value $<0.05(0,003)$. 3) entrepreneurial motivation and entrepreneurship education together have a strong influence and direction of entrepreneurial intention (44.6\%), while 54.4\% are influenced by other variables not examined by researcher.
\end{abstract}

\begin{abstract}
ABSTRAK
Penelitian ini bertujuan untuk mengetahui pengaruh dari entrepreneurial motivation dan entrepreneurship education terhadap entrepreneurial intention pada Fakultas Manajemen Bisnis Universitas Ciputra. Sampel yang digunakan dalam penelitian ini adalah 93 orang mahasiswa. Jenis penelitian adalah penelitian kuantitatif, menggunakan teknik random sampling dan pengumpulan data menggunakan kuisioner. Teknik analisis data yang digunakan adalah korelasi pearson, cronbach alpha, analisis regresi berganda, uji t, uji F, dan uji asumsi
\end{abstract}


klasik. Hasil analisis regresi yang didapat adalah $\hat{\mathrm{Y}}=0,750+0,585 \mathrm{X}_{1}+0,240 \mathrm{X}_{2}$, yang artinya entrepreneurial intention dipengaruhi oleh entrepreneurial motivation dan entrepreneurship education. Berdasarkan hasil analisis dan pembahasan dapat disimpulkan bahwa: 1) entrepreneurial motivation berpengaruh positif dan signifikan terhadap entrepreneurial intention, hal ini dapat dilihat dari hasil analisis regresi berganda (uji $t$ ) diketahui $t_{\text {hitung }}>t_{\text {tabel }}(5,331>1,818)$ dan nilai signifikansi $<0,05(0,000)$. 2) entrepreneurship education berpengaruh positif dan signifikan terhadap entrepreneurial intention, hal ini dapat dilihat dari hasil analisis regresi berganda (uji t) diketahui $t_{\text {hitung }}>t_{\text {tabel }},(3,077>1,818)$ dan nilai signifikansi $<0,05 \quad(0,003)$. 3) entrepreneurial motivation dan entrepreneurship education bersama-sama memiliki pengaruh yang kuat dan searah dengan entrepreneurial intention (44,6\%). 54,4\% lainnya dipengaruhi oleh variabel lain yang tidak diteliti oleh peneliti.

Keywords: entrepreneurial intention, entrepreneurial motivation, entrepreneurship education.

\section{PENDAHULUAN}

Indonesia merupakan salah satu negara yang memiliki banyak sumber daya, tetapi memiliki tingkat perekonomian yang berada jauh di bawah negara lain. Penyebabnya adalah kurangnya motivasi yang dimiliki oleh masyarakat Indonesia dalam mengelola sumber daya yang tersedia untuk menjadi sebuah bisnis.

Ciputra dan Waluyo (2014: 39) menyatakan bahwa $12 \%$ keragaman hayati dunia ada di Indonesia. Namun generasi terdidik yang dihasilkan oleh lembaga pendidikan masih belum sanggup meng-entrepreneur-kan banyak peluang yang ada dan lebih banyak lulusan perguruan tinggi yang menganggur. Menurut Adnyana dan Purnami (2016) salah satu cara untuk mengatasi masalah pengangguran di Indonesia adalah dengan cara memberdayakan masyarakat dan generasi muda melalui program entreprenenur yang diharapkan akan mampu berkontribusi di dalam penyerapan tenaga kerja, sehingga dapat me- ngurangi pengangguran dan beban negara.

Azwar (2013) mengemukakan bahwa menumbuhkan jiwa kewirausahaan para mahasiswa perguruan tinggi merupakan alternatif untuk mengurangi tingkat pengangguran. Para sarjana diharapkan dapat menjadi entrepreneur muda terdidik yang mampu merintis usahanya sendiri. Dunia bisnis masa kini dan masa depan lebih mengandalkan knowledge dan intellectual capital, sehingga dapat menjadi daya saing bangsa. Pengembangan wirausaha muda perlu diarahkan pada kelompok muda terdidik.

Pemahaman bahwa pembelajaran entrepreneur harus mulai ditanamkan pada para mahasiswa perguruan tinggi agar tidak menambah jumlah pengangguran di Indonesia. Ciputra mendirikan lima belas sekolah dan empat universitas yang berbasis bisnis. Salah satunya adalah Universitas Ciputra yang didirikan tahun 2006 di Surabaya, dengan visi menjadi 
sebuah universitas yang menciptakan entrepreneur kelas dunia yang berkarakter dan memberi sumbangsih bagi nusa dan bangsa (Ciputra, 2012). Visi tersebut bisa dicapai apabila setiap mahasiswa dari semua jurusan wajib mengambil mata kuliah entrepreneurship selama lima semester (dari semester satu sampai dengan semester lima).

Pembelajaran bisnis lebih banyak diterima oleh mahasiswa $\mathrm{Fa}$ kultas Manajemen Bisnis. Fakultas Manajemen Bisnis Universitas Ciputra bertujuan untuk menghasilkan lulusan ekonomi yang tidak hanya mampu dalam mengelola manajemen dan akuntansi, tetapi juga mampu untuk membaca peluang pasar, memperhitungkan risiko, dan memiliki kemandirian, serta selalu berinovasi dalam menciptakan usaha (Ciputra, 2012).

Penelitian pendahuluan menemukan alasan dari responden mahasiswa ketika memilih berkuliah di Universitas Ciputra terutama karena pendidikan entrepreneurial-nya. Hal ini berlawanan dengan keinginan terbesar para responden setelah lulus dari Universitas Ciputra yakni menjadi karyawan. Hasil ini menunjukkan bahwa motivasi dari mahasiswa untuk ber-entrepreneur masih sangat rendah meskipun telah mendapatkan berbagai pelatihan yang menunjang mahasiswa untuk ber-entrepreneur (Pratama, 2015).

Berwirausaha dimulai dengan adanya entrepreneurial intention yang mana minat atau bakat merupakan faktor penentu dalam menjalankan usaha. Enterepreneurial Intention adalah niat seorang individu dalam mengambil tindakan dan membuat keputusan. Hal ini juga mencerminkan motivasi dan tujuan dari individu tersebut (Peng et al., 2015).

Motivasi adalah dorongan yang menggerakkan orang untuk melakukan aksi. Menurut Sampurna (2015) entrepreneurial motivation adalah dorongan sebagai penggerak untuk membangkitkan semangat dalam memenuhi tujuan berwirausaha. Calon entrepreneur yang memiliki entrepreneurial motivation yang rendah, biasanya menunjukkan rendahnya entrepreneurial intention yang dimilikinya dalam menjalankan bisnis, sehingga menjadi takut untuk mengambil risiko (Sampurna, 2015).

Seorang entrepreneur yang memiliki entrepreneurial motivation dan entrepreneurial intention yang tinggi tidak menjamin kesuksesannya tanpa disertai entrepreneurship education (Sampurna, 2015). Fatoki (2014) menyatakan entrepreneurship education menjadi faktor penting dalam menumbuhkan dan mengembangkan keinginan, jiwa dan perilaku berwirausaha di kalangan generasi muda, karena pendidikan merupakan sumber sikap dan niat keseluruhan untuk menjadi wirausahawan sukses akan datang.

Peng et al. (2015) menunjukkan bahwa variabel self efficacy berpengaruh positif dan signifikan terhadap entrepreneurial intention. Penelitian Thesman dan Ardianti (2014) menunjukkan adanya hubungan yang spesifik antara variabel entrepreneurial motivation (khususnya dimensi egoistic passion) dan variabel kinerja bisnis. Penelitian Adnyana dan Purnami (2016) menuliskan bahwa pendidikan kewirausahaan, self efficacy, dan locus of control berpengaruh positif dan signifikan pada niat berwirausaha mahasiswa. 
Perbedaan dari beberapa penelitian di atas adalah penelitian ini menggunakan variabel entrepreneurial motivation, entrepreneurship education dan entrepreneurial intention. Berdasarkan data dan beberapa penelitian di atas, maka peneliti melakukan penelitian mengenai pengaruh entrepreneurial motivation dan entrepreneurship education terhadap entrepreneurial intention pada mahasiswa di Fakultas Manajemen Bisnis Universitas Ciputra.

\section{TINJAUAN PUSTAKA \\ Entrepreneurial Motivation}

Entrepreneurial motivation adalah dorongan dalam diri individu untuk menciptakan bisnis dan mempertahankan semangat kewirausahaan dalam semua tindakannya demi mencapai tujuan kewirausahaan (Thesman dan Ardianti, 2014). Thesman dan Ardianti (2014) menyatakan terdapat empat dimensi dari entrepreneurial motivation, yaitu:

a. Need for achievement: mengacu pada keinginan untuk melakukan tugas yang sulit sesuai dengan tantangan (Thesman dan Ardianti, 2014). Dimensi yang diteliti adalah (1) menyukai tanggung jawab pribadi dalam mengambil keputusan, (2) mengambil risiko sesuai dengan kemampuannya, dan (3) memiliki minat untuk selalu belajar dari keputusan yang diambil (Sampurna, 2015).

b. Locus of control: mengacu pada keyakinan individu mengenai kontrol yang dimiliki terhadap kehidupan personal mereka (Thesman dan Ardianti, 2014). Dimensi yang diteliti adalah yakin bahwa (1) kepemimpinan sangat bergantung pada kemampuan, dan (2) keber- hasilan yang terjadi karena hasil kerja keras sendiri (Adnyana dan Purnami, 2016).

c. Self-efficacy: mengacu pada keyakinan individu terhadap kemampuan sendiri untuk mengumpulkan dan menerapkan sumber daya, keterampilan, serta kompetensi pribadi dalam melakukan pencapaian pada tingkat tertentu dari tugas yang diberikan. Dimensi yang diteliti adalah (1) kepercayaan diri yang kuat bahwa saya mampu, dan (2) kepercayaan diri yang kuat bahwa saya kompeten (Thesman dan Ardianti, 2014).

d. Opportunity: motivasi yang mendorong entrepreneur dalam memulai usaha disebabkan adanya peluang yang terbuka atau tidak (Thesman dan Ardianti, 2014). Dimensi yang diteliti adalah adanya peluang untuk (1) mendirikan usaha baru, (2) menciptakan produk baru, dan (3) memasuki pangsa pasar baru.

\section{Entrepreneurship Education}

Fatoki (2014) menyatakan entrepreneurship education menjadi faktor penting dalam menumbuhkan dan mengembangkan keinginan, jiwa dan perilaku berwirausaha dikalangan generasi muda karena pendidikan merupakan sumber sikap dan niat keseluruhan untuk menjadi wirausahawan sukses pada waktu akan datang. Adnyana dan Purnami (2016) menyatakan ada tiga dimensi yang mempengaruhi entrepreneurship education, yakni: (1) menumbuhkan keinginan berwirausaha, (2) menumbuhkan kesadaran adanya peluang bisnis, dan (3) menambah ilmu dan wawasan dalam bidang wirausaha. 


\section{Entrepreneurial Intention}

Enterepreneurial Intention adalah niat seorang individu dalam mengambil tindakan dan membuat keputusan. Hal ini juga mencerminkan motivasi dan tujuan dari individu tersebut (Peng et al., 2015). Sampurna (2015) menyatakan ada tiga dimensi dalam mengukur entrepreneurial intention, yakni: (1) keinginan memilih wirausaha sebagai karir atau profesi, (2) lebih menyukai menjadi wirausaha dari pada bekerja pada orang lain, dan (3) memiliki rencana untuk memulai bisnis di masa depan.

\section{HIPOTESIS PENELITIAN}

Hipotesis yang diajukan pada penelitian ini adalah:

1. Hipotesis pertama (H1):

Entrepreneurial motivation berpengaruh terhadap entrepreneurial intention pada mahasiswa Fakultas Manajemen Bisnis Universitas Ciputra.

2. Hipotesis kedua $(\mathrm{H} 2)$ :

Entrepreneurship education berpengaruh terhadap entrepreneurial intention pada mahasiswa Fakultas Manajemen Bisnis Universitas Ciputra.

\section{METODE PENELITIAN Jenis Penelitian}

Jenis penelitian yang digunakan adalah kuantitatif deskriptif. Penelitian kuantitatif deskriptif bertujuan menjelaskan dan menyederhanakan berbagai situasi, kondisi atau variabel yang timbul di masyarakat yang menjadi objek penelitian (Bungin, 2014: 44). Penelitian kuantitatif deskriptif dilakukan dengan metode survei, yaitu mengumpulkan data berdasarkan kuisioner. Kuisioner berisikan daftar pernyataan dari variabel yang diteliti. Responden diberikan kuisioner kemudian diminta untuk menjawab pernyataan dengan pilihan jawaban skala likert. Skala Likert adalah teknik yang digunakan untuk mengukur sikap, pendapat, dan persepsi seseorang atau sekelompok orang tentang fenomena sosial (Sugiyono, 2015: 136).

\section{Populasi, Sampel dan Sampling}

Populasi dari penelitian ini adalah mahasiswa Fakultas Manajemen Bisnis Universitas Ciputra angkatan 2012 dan 2013 yang berjumlah 573 orang. Dari jumlah populasi, jumlah sampel yang diambil adalah sebanyak 93 orang. Penelitian ini menggunakan random sampling pada responden yang memenuhi kriteria yaitu: 1) Terdaftar sebagai mahasiswa aktif Fakultas Manajemen Bisnis Universitas Ciputra, dan 2) Telah mendapat pelajaran entrepreneurship satu sampai lima.

\section{Teknik Analisis Data}

Teknik analisis data yang digunakan adalah uji validitas, uji reliabilitas, analisis regresi berganda, uji t, uji $\mathrm{F}$, uji koefisien korelasi dan koefisien determinasi, dan uji asumsi klasik (uji normalitas, uji heterokedastisitas, uji multikolinearitas, uji autokorelasi, dan uji linearitas).

\section{HASIL PENELITIAN}

Berdasarkan uji validitas (korelasi Pearson) diketahui semua pernyataan dari variabel entrepreneurial motivation, entrepreneurship education dan entrepreneurial intention dinyatakan valid. Hal itu dibuktikan dari nilai signifikansi $<0,05$. Berdasarkan uji reliabilitas (cronbach alpha) semua pernyataan dinyatakan reliabel 
karena memiliki nilai cronbach alpha yang dihitung $>0,6$, yaitu variabel entrepreneurial motivation $(0,784)$, entrepreneurship education $(0,754)$, dan entrepreneurial intention $(0,706)$.

Hasil analisis regresi berganda yang dilakukan dengan menggunakan SPSS 21.0, menunjukkan bahwa entrepreneurial motivation dan entrepreneurship education berpengaruh terhadap entrepreneurial intention. Hal ini dapat dilihat dari persamaan regresi yang dihasilkan, yaitu $\hat{Y}=$ $0,750+0,585 X_{1}+0,240 X_{2}$. Berdasarkan persamaan tersebut terlihat bahwa koefisien regresi dari masing-masing variabel bebas bernilai positif antara entrepreneurial motivation, dan entrepreneurship education secara bersamasama berkontribusi terhadap entrepreneurial intention.

Hasil dari uji hipotesis pertama diketahui bahwa arah koefisien regresi dari variabel entrepreneurial motivation sebesar 0,585 bernilai positif, yang berarti semakin baik entrepreneurial motivation, maka semakin tinggi entrepreneurial intention atau sebaliknya semakin buruk entrepreneurial motivation mahasiswa maka semakin rendah pula entrepreneurial intention. Berdasarkan uji $\mathrm{t}$ untuk variabel entrepreneurial motivation diperoleh $t_{\text {hitung }}>\mathrm{t}_{\text {tabel, }}$ yaitu 5,331 $>$ 1,818 dan nilai signifikansi $(0,000)<$ 0,05 .

Hasil dari uji hipotesis kedua diketahui bahwa arah koefisien regresi dari variabel entrepreneurship education sebesar 0,240 bernilai positif, yang berarti semakin baik entrepreneurship education maka semakin tinggi entrepreneurial intention atau sebaliknya semakin buruk entrepreneurship education mahasiswa, maka semakin rendah pula entrepreneurial intention. Berdasarkan uji t untuk variabel entrepreneurship education diperoleh $t_{\text {hitung }}>\mathrm{t}_{\text {tabel}}$, yaitu 3,077 $>$ 1,818 dan nilai signifikansi $(0,003)<$ 0,05 .

Hasil uji $\mathrm{F}$ diketahui bahwa $\mathrm{F}_{\text {hitung }}>\mathrm{F}_{\text {tabel, }}$ yaitu $36,191>3,09$ dengan nilai signifikansi $(0,000)<$ 0,05 . Hal ini menunjukkan bahwa entrepreneurial intention memiliki kecenderungan yang sama dengan adanya kombinasi yang diikuti oleh peningkatan entrepreneurial motivation dan entrepreneurship education, yang berarti bahwa semakin baik entrepreneurial motivation dan entrepreneurship education maka akan meningkatkan entrepreneurial intention dan sebaliknya apabila entrepreneurial motivation dan entrepreneurship education semakin buruk maka dapat menurunkan entrepreneurial intention. Koefisien determinasi sebesar 44,6\% menunjukkan bahwa ada pengaruh yang diberikan oleh kombinasi variabel entrepreneurial motivation dan entrepreneurship education sebesar 44,6\% terhadap entrepreneurial intention, dan $55,4 \%$ dari variabel entrepreneurial intention yang dijelaskan oleh variabel lain yang tidak diteliti pada penelitian ini.

Uji normalitas dilakukan untuk mengetahui apakah dalam sebuah regresi variabel dependen, variabel independen, atau keduanya memiliki distribusi normal atau mendekati normal. Pengujian dengan menggunakan uji Kolmogorov-Smirnov dan dilihat dari hasil analisis, entrepreneurial motivation, entrepreneurship education, dan entrepreneurial intention memiliki nilai sig $(0,191)>0,05$. Jadi dapat disimpulkan bahwa penelitian ini berdistribusi secara normal. 
Uji multikolinearitas dilakukan untuk mengetahui apakah dalam model regresi ditemukan terjadinya korelasi antara variabel atau tidak. Penelitian ini menggunakan Variance Inflation Factor (VIF). Pedoman model regresi yang bebas multikolinearitas adalah di atas angka 0,1 dan dibawah angka 10 (batas VIF). Hasil nilai dari Tolerance value dan VIF untuk variabel entrepreneurial motivation dan entrepreneurship education sama, yaitu sebesar 0,750 dan 1,333 . Jadi disimpulkan bahwa pada penelitian tidak terjadi multikolinearitas.

Uji heterokedastisitas dilakukan untuk mengetahui apakah terjadi perbedaan varian dari residual satu pengamat ke pengamat lain. Penelitian ini menggunakan uji Glejser, di mana nilai sig $>0,05$. Nilai sig dari entrepreneurial motivation $(0,27)$, dan entrepreneurship education (0,331). Jadi disimpulkan bahwa pada penelitian tidak terjadi heterokedastisitas.

Uji autokorelasi untuk mengetahui hubungan kekuatan antara residual. Alat uji statistik yang digunakan adalah Durbin-Watson ( $\left.d_{\text {hitung }}\right)$, dengan ketentuan nilai $d u<$ $d_{\text {hitung }}<4-d u$ maka tidak terjadi autokorelasi. Nilai Durbin Watson dalam penelitian ini berada diantara rentang $d u$ dan (4- $d u)$, yaitu $1,709<2,208<2,291$, sehingga disimpulkan bahwa pada penelitian tidak terjadi autokorelasi.

Hasil uji linearitas yang digunakan untuk mengetahui apakah model hubungan antara variabel bebas dan variabel terikat terjadi secara linear atau tidak. Teknik pengujian yang digunakan adalah test of linearity dengan kriteria nilai sig. $\leq 0,05$. Hasil uji dari test of linearity menunjukkan nilai sig entrepreneurial motivation $(0,000)$, dan entrepreneurship education $(0,000)$. Jadi disimpulkan bahwa hubungan antara variabel bebas dan terikat pada penelitian bersifat linear.

\section{PEMBAHASAN}

Pengaruh Entrepreneurial Motivation terhadap Entrepreneurial Intention

Berdasarkan hasil uji t dengan nilai signifikansi $0,000<0,05$, berarti entrepreneurial motivation $\left(\mathrm{X}_{1}\right)$ berpengaruh signifikan terhadap entrepreneurial intention (Y) mahasiswa pada Fakultas Manajemen Bisnis Universitas Ciputra khususnya pada angkatan 2012-2013. Sesuai dengan pemahaman tersebut, maka hipotesis pertama, yaitu: "Entrepreneurial motivation berpengaruh secara signifikan terhadap entrepreneurial intention pada mahasiswa Fakultas Manajemen Bisnis Universitas Ciputra" dapat diterima.

Hasil penelitian di atas didukung oleh penelitian terdahulu yang dilakukan oleh Achchuthan and Nimalathasan (2013) yang membuktikan bahwa entrepreneurial motivation berpengaruh secara signifikan terhadap entrepreneurial intention.

\section{Pengaruh Entrepreneurship Educa- tion terhadap Entreprenneurial Intention}

Berdasarkan hasil uji t dengan nilai signifikansi $0,003<0,05$, berarti entrepreneurship education $\left(\mathrm{X}_{2}\right)$ berpengaruh signifikan terhadap entrepreneurial intention (Y) mahasiswa Fakultas Manajemen Bisnis Universitas Ciputra khususnya pada angkatan 2012-2013. Sesuai dengan pemahaman tersebut, maka hipotesis kedua, yaitu: "Entrepreneurship education berpengaruh secara signifikan 
terhadap entrepreneurial intention pada mahasiswa Fakultas Manajemen Bisnis Universitas Ciputra" dapat diterima.

Hasil penelitian di atas didukung oleh penelitian terdahulu yang dilakukan oleh Adnyana dan Purnami (2016) yang membuktikan bahwa entrepreneurial motivation berpengaruh secara signifikan terhadap entrepreneurial intention.

\section{KESIMPULAN}

Berdasarkan hasil pembahasan di atas, maka dapat disimpulkan bahwa entrepreneurial motivation dan entrepreneurship education berpengaruh secara signifikan terhadap entrepreneurial intention pada mahasiswa Fakultas Manajemen Bisnis Universitas Ciputra.

Peneliti menyadari adanya keterbatasan dalam menyelesaikan penelitian ini. Penelitian ini: (1) menggunakan subjek yang terbatas sehingga hasilnya tidak dapat digeneralisasikan ke subjek berjumlah besar, (2) terdapat data yang tidak lengkap dan tidak sesuai dengan harapan peneliti, (3) teknik penyebaran kuisioner yang terbatas sehingga responden yang didapat tidak sepenuhnya di-random.

\section{SARAN}

Perlunya peningkatan intention dalam ber-entrepreneurial pada mahasiswa Fakultas Manajemen Bisnis Universitas Ciputra dengan: (1) menambah pelatihan leadership dan seminar bisnis pada semua mahasiswa, (2) memberikan penghargaan kepada mahasiswa Fakultas Manajemen Bisnis dengan kategori tertentu, (3) membuat komunitas bisnis yang menjadi sarana bagi mahasiswa untuk berdiskusi, dan bertukar informasi serta menjalin kerja sama diantara mahasiswa menjalankan project bisnis.

Saran untuk penelitian selanjutnya adalah dengan: (1) menambah jumlah sampel dalam penelitian, (2) menggunakan teknik pengambilan sampel yang lain, sehingga ditemukan hasil yang dapat digeneralisasi, (3) mempertimbangkan variabel-variabel lain yang dapat menjelaskan variabel dalam model penelitian ini (dengan menambah indikator dan dimensi yang dapat dipertimbangkan untuk ditambahkan pada variabel).

\section{DAFTAR PUSTAKA}

Achchuthan, Sivapalan and B. Nimalathasan, 2013, Relationship Between Entrepreneurial Motivation and Entrepreneurial Intention: A Case Study of Management Undergraduates of The University of Jaffna, Sri Lanka, International Conference on Business Management, page 42-50.

Adnyana, I Gusti Lanang Agung dan Ni Made Purnami, 2016, Pengaruh Pendidikan Kewirausahaan, Self Efficacy dan Locus of Control pada Niat Berwirausaha, E-Jurnal Manajemen Unud, Vol. 5, No. 2, hal. 1160-1188.

Augustine, Y. dan R. Kristaung, 2013, Metodologi Penelitian Bisnis dan Akuntansi, Dian Rakyat, Jakarta.

Azwar, B., 2013, Analisis Faktorfaktor yang Mempengaruhi Niat Kewirausahaan (Entrepreneurial Intention): Studi Terhadap Mahasiswa Universitas Islam Negeri SUSKA Riau, Menara, Vol. 12, No. 1, hal. 12-22. 
Bungin, B., 2014, Metode Penelitian Kuantitatif, Kencana Prenada Media Group, Jakarta.

Ciputra, Tanan A. dan A. Waluyo, 2014, Ciputra Quantum Leap 2, PT. Elex Media Komputindo, Jakarta.

Ciputra, U., 2012, Buku Pedoman Mahasiswa Universitas Ciputra, Universitas Ciputra, Surabaya.

Fatoki, O., 2014, The Entrepreneurial Intention of Undergraduate Students in South Africa: The Influences of Entrepreneurship Education and Previous Work Experience, Mediterranean Journal of Social Sciences, Vol. 5, No. 7, page 294-299.

Gunawan, Sherly dan R.R. Retno Ardianti, 2013, Analisa Entrepreneurial Motivation dan Inovasi Produk pada Pelaku Usaha Mikro dan Kecil di Jawa Timur pada Sektor Informal, Agora, Vol. 1, No. 3.

Handaru, Agung Wahyu, Widya Parimita, Adzhani Achmad dan Chitra Nandiswara, 2014, Pengaruh Sikap, Norma Subjektif, dan Efikasi Diri Terhadap Intensi Berwirausaha Mahasiswa Magister Managemen (Kajian Empiris pada Sebuah Universitas Negeri di Jakarta), Jurnal Universitas Paramadina, Vol. 11, No. 2, hal. 1046-1061.

Hussain, A., 2015, Impact of Entrepreneurship Education on Entrepreneurial Intentions of Pakistani Students, Journal of Entrepreneurship and Business Innovation, Vol. 2, No. 1, page 43-53.
Kuncoro, M., 2013, Metode Riset untuk Bisnis dan Ekonomi, Erlangga, Jakarta.

Lantan, H. dan Temalagi, 2013, Analisis Multivariate Teknik dan Aplikasi Menggunakan Program IBM SPSS 20.0., Alfabeta, Bandung.

Lind, D. A., W. G. Marchal, dan S. A. Wathen, 2014, Teknik-Teknik Statistika dalam Bisnis \& Ekonomi, Salemba Empat, Jakarta.

Negash, E. and C. Amentie, 2013, An Investigation of Education Student's Entrepreneurial Intention in Ethiopian University: Technology and Business Field in Focus, Basic Research Journal, page 1-22.

Peng, Y. L., R. Kong and C.G. Turvey, 2015, Impacts of Self-efficacy on Perceived Feasibility and Entrepreneurial Intentions: Empirical Evidence from China, International Conference of Agricultural Economists, page 1-22.

Pratama, G. 2015, Peran Mediasi Motivasi Intrinsik pada Hubungan Entrepreneurial Intention dan Entrepreneurial Action di Lingkungan Entrepreneurial Universitas Ciputra, 1-5.

Sampurna, A.A., 2015, Minat Berwirausaha Ditinjau dari Motivasi Berwirausaha dan Prestasi Belajar Mata Pelajaran Kewirausahaan pada Siswa Kelas XI Program Keahlian Karawitan dan Seni Tari SMK Negeri 8 Surakarta.

Sugiyono, 2015, Metode Penelitian Kuantitatif, Kualitatif dan Kombinasi (Mixed Method), Alfabeta, Bandung. 
Sujarweni, V. W., 2015, SPSS Untuk Penelitian, Pustaka Baru Press, Yogayakarta.

Thesman, T. dan R. Ardianti, 2014, Hubungan Entrepreneurial Motivation terhadap Kinerja Bisnis Usaha Mikro dan Kecil pada Sektor Makanan dan Minuman di Surabaya dan Sidoarjo, Agora, Vol. 2, No. 2. 